\title{
A STUDY ON TONGUE ROLLING, TONGUE FOLDING AND CERUMEN TYPE IN A NIGERIA POPULATION
}

EBEYE OLADUNNI ABIMBOLA

Correspondence to Ebeye Oladunni Abimbola Department of Anatomy, Faculty of Basic Medical Sciences, College of Health Sciences, Delta State University, Abraka, Nigeria. Email: princessebeye@gmail.com

\begin{abstract}
This study investigated Variation in cerumen type, tongue rolling and tongue folding abilities of the Esan people of Southern Nigeria. This cross-sectional survey investigated 400 volunteered adult subjects (176 males and 224 females) between the ages of 18 and 60 whose parents and grandparents were of Esan ethnicity. The tongue and ear wax type were observed and examined physically thus classifying subjects into rollers/none-rollers, folders/none-folders and dry or wet cerumen type. Results indicates that tongue rollers $(72.9 \%)$ were more than non-rollers $(27.3 \%)$, in the same vein, tongue folders $(68.3 \%)$ were also more than non-folders $(31.7 \%)$ in the studied population. A larger percentage of the population also had wet ear wax $(65 \%)$ while $(35 \%)$ had dry ear wax. The chisquared analysis of variance showed that there is a significant difference $(P<0.05)$ between those who can roll their tongue and those who cannot, those that could fold their tongue and those who cannot as well as between those with wet ear wax and dry ear wax. This study therefore provides data on the distribution of tongue rollers, tongue folders as well as variability in cerumen type. This data can be of importance to the anthropologist and forensic investigators.
\end{abstract}

Key Words: Variation, Genetics, Inheritance, tongue rolling, tongue folding, cerumen type

\section{INTRODUCTION}

Studies have shown that no two individuals are exactly the same; differences occurring in humans could be as a result of selection, migration and mode of inheritance (Bhasin et al., 1992). Inheritance is the mode of transmitting biological traits from parents to offspring through gene (Ordu et al., 2014).

The understanding of the principle of inheritance enables geneticists to predict the possibility of an offspring acquiring certain traits from parents (Hugo et al., 2003). The genetic constitution of organism is manifested phenotypically as observable trait like earlobe attachment, rolling and folding of tongue and cerumen type. The mode of inheritance describes how allele work together to produce traits (Rostand and Tétry 1964).

Genes are composed of two or more variates, called alleles. Individuals may inherit two identical or two different alleles from their parents which may interact in dominant and recessive manner. For example, the alleles for tongue rolling/folding are dominant over none rolling/none folding.

The tongue is a mobile organ made up of muscular tissues and covered with mucosa membrane; it can assume various shapes and forms (Keith and Arthur 2006). It is involved in production of sounds, deglutition and taste. The aptness to roll the lateral edge of the tongue in an upward manner into a tube is tongue rolling. The muscles of the tongue allow some individuals to fold their tongues into specific shapes and roll their tongue into a tube. The rolling and folding of the tongue is often described as a dominant trait with simple mendelian inheritance. The dominant gene is believed to be responsible for folding and rolling of the tongue while the inability to roll and fold the tongue is associated with recessive gene (Hsu, 1948). A study by Sturtevant in 1940 classified the ability to manipulate the tongue into rollers and non- rollers, with the roller being dominant. He also noted that about 
$70 \%$ of people of Europeans are able to roll up the lateral edges of the tongue, while the remaining 30\% could not (Sturtevant, 1940). Odokuma et al., also observed a higher incidence of rollers and folder among the Urhobo people of Nigeria (Odokuma et al., 2008). Maishnam reported higher percentage of rollers and folders in six different type tribes of Manipur, India (Maishnam, 2012).

Ear wax also known as cerumen is a yellowish waxy substance secreted in the ear canal by sebaceous glands located in them. It is for protection, cleaning and lubricating the canal. Ear wax could be wet or dry. Wet ear wax is taught to be inherited in dominate manner following simple mendelians law. East Asians and Native Americans also have less of wet type of cerumen. Africans and Europeans on the other hand are more likely to have the wet type. According to Theresa, Cerumen type has been used by anthropologists to track human migratory patterns, such as those of the Eskimos (Bass and Jackson 1977).

These morphologic traits although believed to be passed from parent to offspring in a simple Mendelian pattern is been argued and it is now believed that environmental factors also has a part to play (Overfield, 1985)

The variability of these traits among population can be useful to the physical anthropologist and forensic experts in studying population. This study therefore seeks to provide standard data on the distribution and variability pattern of tongue rolling, tongue folding and cerumen type among the Esan ethnic group of Nigeria.

\section{METHODOLOGY}

This cross-sectional survey adopted the simple random sampling technique in choosing 400 (176 males and 224 females) subjects between the ages of $18-60$ years after ethical approval from the Department of Anatomy and Cell Biology, Delta State University, Abraka. Their parents up to second generation were Esan people. Consent was sort and given by subjects. Tongue rolling and folding status as well as cerumen type was determined by physical examination. The following were identified;

1. Tongue roller: Subjects who could roll the lateral edges of the tongue upwards into a tube were classified as roller.
2. Tongue folder: Subjects who have the ability to roll their tongue into various shapes are classified as folders.

3. Cerumen type: Cerumen type was classified as either wet or dry, wet earwax is sticky and yellowish to brown in colour while dry is crumbly and gray to tan. Ear wax was cleaned and observed with the aid of cotton bud.

Data obtained was subjected to statistical analysis using SPSS version 20. Frequency distribution was used to assess most prevalent traits. Chi square was then used to determine association between traits and gender.

\section{RESULTS}

Table 1 depicts frequency distribution of tongue roller and folders as well as cerumen type among male and female Esan people of southern Nigeria.

Table 1: Frequency distribution of some Morphogenetic trait in Esan ethnic group of Nigeria

\begin{tabular}{|l|l|l|l|l|l|l|}
\hline Sex & \multicolumn{2}{l|}{ TONGUE FOLDING } & \multicolumn{2}{l|}{ TONGUE ROLLING } & \multicolumn{2}{l|}{ CERUMEN TYPE } \\
\hline & Folders & Non-folder & Rollers & Non-roller & Dry & Wet \\
\hline Male $(n=176)$ & $125(71.0 \%)$ & $51(28.9 \%)$ & $123(69.9 \%)$ & $53(30.1 \%)$ & $58(33.0 \%)$ & $118(67.0 \%)$ \\
\hline $\begin{array}{l}\text { Female } \\
(n=224)\end{array}$ & $148(66.1 \%)$ & $76(33.9 \%)$ & $168(75.0 \%)$ & $56(25.0 \%)$ & $82(36.6 \%)$ & $142(63.4 \%)$ \\
\hline M \& F(n=400) & $273(68.3 \%)$ & $127(31.7 \%)$ & $291(72.7 \%)$ & $109(27.3 \%)$ & $140(35.0 \%)$ & $260(65.0 \%)$ \\
\hline
\end{tabular}


Anatomy Journal of Africa. 2019. Vol 8 (2): 1540 - 1543

\section{DISCUSSION}

Morphogenetic traits can be used to investigate differences that arise within and among different populations due to genetic variations. The knowledge and understanding of inheritance pattern help geneticists to predict the possibility of an offspring inheriting certain traits from parents (Ordu et al., 2014).

Variation in cerumen type, tongue rolling and tongue folding among the Esan's of Edo state, Nigeria was investigated as shown in Table 1 above. A higher occurrence of folders $(68.3 \%)$ and rollers $(72.7 \%)$ were observed in the population studied. Chi-squared analysis of variance showed there is a significant difference $(P<0.05)$ between those who could roll and fold their tongue and those who cannot. The findings above are similar to the study of Alfred Sturtevant among Europeans, Odokuma et al., among the Urhobo people of Nigeria and Maishnam Rustam Singh in six different type tribes of Manipur, India and that of Bulliyya among Vannekula Kshatriya caste population of Andhra. (Sturtevant, 1940; Bulliyya, 2003; Odokuma et al., 2008; Maishnam, 2012).

When males were compared with females, a higher percentage $(71.0 \%)$ were folders as compared to $(66.1 \%)$ female folders. The opposite was observed in rollers as a higher percentage $(75.0 \%)$ of females could roll their tongue as compared to $(69.9 \%)$ of males. There was, however, no statistically significant association between gender among folders and rollers $(P>0.05)$.

These findings were not different from previous studies as reported by Hernandez (1980) who showed that ability to roll the tongue was lower in males as compared to their female counterparts (Hernandez,1980). Likewise, a study conducted by Odokuma et al., amongst unrelated volunteer students of Delta State University, Nigeria, revealed frequency of folders (120) and rollers (87) were more common in females than in their male counterparts but were however, insignificant relative to gender (Odokuma et al., 2008). A similar study amongst Indians showed no significant difference between male and female samples but a lower incidence of tongue rollers and folders (Das and Sengupta 2003).

Result on cerumen type revealed a larger percentage $65 \%$ (Males 29.9\%, Females $35.5 \%$ ) had wet ear wax while $35 \%$ (Males $14.5 \%$, Females $20.5 \%$ ) had dry ear wax. The chi-squared analysis of variance showed that there is a significant difference $(P<0.05)$ between those who had wet ear wax and those who had dry ear wax. Between males and females however, no significant difference was observed $(P>0.05)$. This is at variance with a study done in Indians where it was observed that dry/flaky cerumen is highly frequent in the males while the wet or waxy type predominates in females though the differences was not statistically significant (Jaswant and Sarthak 2004).

In conclusion, there is slight variation in results when compared to other populations. Tongue rolling, tongue folding, and cerumen type can thus be used to investigate the diversity that arises within and among different populations due to genetic diversity.

\section{REFERENCES}

1. Bhasin MK, Walter H and Danker-Hopfe H. 1992. The Distribution of Genetical, Morphological and Behavioural Traits among the People of Indian Region. Kamla-Raj Enterprises, Delhi.

2. Ordu KS, Didia BC, Egbunefu N. 2014. Inheritance Pattern of Earlobe Attachment amongst Nigerians. Greener Journal of Human Physiology and Anatomy; Vol. 2 (1), pp. 001-007

3. Hugo P, Eliaman Q, John K. 2003. History of evolution and its concept.; 6th Ed, New York City 55-66..

4. Rostand J and Tétry A. 1964. An Atlas of Human Genetics. Hutchinson Scientific \& Technical, London 
5. Keith ML and Arthur DF. 2006. Clinical Oriented Anatomy.5th Edition, Lippincott Williams and Wilkins 20-21.

6. Hsu TC. 1948. Tongue up folding: a newly reported heritable character in man. J. Hered;39: $187-188$

7. Sturtevant AH. 1940. A new inherited character in man. Proc. Nat. Acad. Sci. USA, 26: 100-102

8. Odokuma EI, Eghworo O, Avwioro G, Agbedia U. 2008. Tongue rolling and Tongue Folding Traits in an African Population Int. J. Morphol.,26(3):533-53

9. Maishnam Rustam Singh. 2012. Tongue Rolling and Folding in Six Populations of Manipur, India. Frontier Anthropology, $1: 41-45$ @ Anthropological Society of Manipur

10. Bass EJ, Jackson JF. 1977. "Cerumen types in Eskimos". American Journal of Physical Anthropology.47 (2): 209-10

11. Overfield, Theresa. 1985. Biologic variation in health and illness: race, age, and sex differences. Menlo Park, Calif: Addison-Wesley, Nursing Division. p. 46

12. Bulliyya G. 2003. Study on Anthropogenetic traits in a Caste Group of Andhra Pradesh. Anthropologist, 5; 3:197-199.

13. Hernandez M. 1980.La movilidad del pabellon auditivo. Trab. Antropol,XVIII (4): 199-203

14. Das B, Sengupta S. 2003. A Note on Some Morphogenetic Variables among the Sonowal Kacharis of Assam. Anthropologist, 5(3): 211-212.

15. Jaswant Singh and Sarthak Sengupta. 2004. Some Morpho-genetic and Behavioural Traits Among the Assamese Sikhs Anthropologist,6(4): 253-255 